\title{
The Politics of Development Strategies in Nigeria Since Independence: An Overview
}

\author{
Dr. Ozy B. Orluwene, JP \\ Department of Political Science, Ignatius Ajuru (Rivers State) University of Education, \\ P.M.B. 5047, Port Harcourt, Nigeria \\ Email: ozywene@gmail.com
}

\author{
Doi:10.5901/ajis.2014.v3n6p391
}

\begin{abstract}
This paper is an overview of the development strategies in Nigeria since independence. The paper discovered and observed that the politics of non-continuity and lack of accountability in public policies and programmes in Nigeria since independence as the major reasons of non-actualisation of these development strategies. The study relied essentially on secondary data, while personal observation was equally employed as a method of data generalization. Content analysis was used as a method of data analysis. Based on the data collected and analysed, the paper submits that the politics of non-continuity and lack of accountability of development policies and programmes hampered Nigeria development strategies. The commonest testimonies of these observations and findings are that the wide spread expectation, interest and debate exhibited before and after the inauguration of a government or administration is dampened because of the politics of non-continuity and lack of accountability. The study essentially recommends that government policies and programmes that are people-centred and people-oriented should be enhanced and continued as to create the greatest happiness for the greatest number.
\end{abstract}

Keywords: Development, Nigeria, Policy, Politics and Programmes

\section{Introduction}

Nigeria stands out as an example of a country since its political independence in 1960 that had tried all recommended economic reforms as strategies for economic development. For a summary of the strategies adopted in Nigeria to be presented properly, it is necessary to have a brief survey of what the economy looked like in the colonial period (Ogbuagu, 1995).

A vast majority of Nigerians during the colonial period engaged in subsistence agriculture. A conservative estimate holds that over $80 \%$ of the country's farmers engaged in these farming activities with simple tools. They largely produced primary goods which were largely exported to the metropolitan countries for their manufacturing industries. The production of primary products accounted for foreign exchange earnings and this could not sustain the rate of economic growth and development considered necessary for the nation (Ayida, 1987).

This was based on the fact that the British government that colonised Nigeria made little or no effort to strengthen the economy to diversify to other sectors of economic production. For example, industrialisation was not encouraged; Nigeria was made to look up to Britain for all her manufactured goods. To sustain these adverse and exploitative economic relations, the British government invested in infrastructures such as railways and feeder roads that were essential, to support the evacuation of primary products. The communication network that existed was also invaluable for the distribution in Nigeria of manufactured goods from Britain (Ogbuagu, 1995).

The paper therefore, takes a hard look at a chequered overview of developmental strategies in Nigeria since independence. Relying on historical and contemporary data, it maintains that the supervening instrumentalist in the Nigerian state accounts for the politics of non-continuity and lack of accountability which are essentially why various developmental strategies in Nigeria are hampered and the objectives not realised. The paper concludes by surmising that the people-oriented and people-centred policies and programmes should be enhanced, continued and strengthened. For these would make for the conversion of abundant human and material resources into prosperity for more victors and less victims in Nigeria, thus greatest happiness for the greatest number.

\section{Conceptual Clarification}

This works commences by making some pertinent comments that clarifies and situates our analysis. We accept that development is a concept with multi-dimensional meanings (Orluwene, 2008). Many scholars view development from 
different perspectives based on their state of existence, such as political, economic, social, cultural, technological, religious, gender and educational perspectives. On that note, Henry (cited in Nwaorgu, 2006:75) pointed out most emphatically that the word development delineates a vast arena but does not specify what play as being enacted. This is due to the imprecision of the concept and the difficulty of its measurement as a socio-economic phenomenon. However, Heninecke cited in Nwaorgu (2006:75) hold that despite the complex nature of development, social scientist have been able to identify, describe and analyse development, as well as conceptualise developments.

Accordingly, he holds that development is brought about by the neo-colonial conditions. And point to the fact that it merely serves to redefine the very exploitative relationship between the emerging states of Africa and their colonial oppressors. It is in this particular respect that he explains that:

Development has become such an obsession that it is easy to forget that the idea of development is relatively recent. In Africa the idea really started coming into vogue after the early 1960s when many African countries had become independent... and it would appear that this change occurred on account of the initiative of the western world to redefine its relationship with the former colonies in the light of new realities. First, the categories; developed and under developed countries were used in the place of the old partnership of the colonial days expressed in the "Dual Mandate" a new partnership in development was proposed (Ake, 1981).

To Nnadozie (2004:27), man is viewed as both the subject and object of development. Development is taken as the ability and capacity of man to adequately interact with his physical environment and other individuals to constantly improve himself and humanity. This idea is captured very well by Nnoli cited in Nnadozie (2004:27) when he stated:

Development, first and foremost, is a phenomenon associated with changes in man's humanity and creative energies, not in things. It is the unending improvement in the capacity of the individual and society to control and manipulate the forces of nature as well as themselves and other individuals and societies for their own benefit and that of humanity as large. It is a process of actualizing man's inherent capacity to live a better and more rewarding life. It implies increasing skill and capacity to do things, greater freedom, and responsibility and material well-being.

Development is also conceived by scholars of Marxist perspective as a dialectical process in which the contradictions between a society's productive forces and relations of production are resolved in a dynamic manner. The contradictions in a society are regarded as the driving forces of development in that society. Development is seen as a social and dynamic process the goal of which is change. The process does not necessarily entail evolution or gradualism, nor does it abhor violence. In fact, according to radical scholars, development as a dialectical process is anti-convention and more often than not involves struggles, violent upheavals and radical changes.

The conception of development in this study shall be guided by the Marxist notion of development. Accordingly, development is conceived as the ability of the people to exploit, manipulates and control their physical environment, as well as themselves and other individuals outside of themselves for the betterment of everybody and that of humanity. It abhors any form of exploitation of man by man.. it also entails the constant improvement in this capacity and ability of the people including the unending increase in their political, social, economic, cultural, psychological and technological capacity and awareness, among other things, to actualize themselves individually and collectively.

The second concept "policy" has also been variously defined. In its simplest sense, "policy" refers to broad statements that reflect future goals and aspirations and provides guidelines for carrying out those goals (Osman, nd). As for Hill (1993:47), the term policy is defined as the product of political influence, determining and setting limits to what the state does. Friedrich in Eme and Onwuka (2011:5) defines 'policy' as:

A proposed course of action of a group, person or government within a given environment providing obstacles and opportunities which the policy was proposed to utilize and overcome in an effort to reach a goal or realise an objective or a purpose.

However, this definition of policy has been criticized by Adeniran cited in Eme and Onwuka (2011) in that it excludes that which is actually done, some manifestation of which indeed helps in understanding the real nature of policies. Akpan (1981:32) gave a more comprehensive definition of "policy" as a form of law made by the governing bodies, organisations to govern, direct, control and regulate members of the organisations". He elaborated by saying that "it may take legal form of laws by the legislature, decisions of government cabinet, of board of directors of public corporations or private companies and even instructions issued by departmental authorities and so on". Anderson cited in Onyishi (2010:25) on the other hand, gave more encompassing definition of policy as "what is actually done as against what is proposed or intended, and it differentiates a policy from a decision, which is a choice among competing alternatives".

Meanwhile, there is a close relationship between public policy and government institution. For a policy to become public policy, it must be adapted, implemented and enforced by some government institutions. Government institutions 
give public policy three distinctive characteristics. First, government lends legitimacy to policies. Government policies are generally regarded as legal obligation that commands the loyalty of citizens. People may regard the policies of other groups and association in society- corporations, churches, professional organisations, civil associations and so forth as important and even binding. But only government policies involve legal obligations.

Second, government policies involve universality, only government policies extent to all people in a society; the policies of other groups or organisations reach only a part of the society. Finally, government monopolizes coercion in society- only government can legitimately imprison violators of its policies. The sanctions that can be imposed by other groups or organisations in a society are more limited. It is precisely this ability of government to command the loyalty of all its citizens, to enact policies governing the whole society; and to monopolize the legitimate use of force that encourages individuals and groups to work for enactment of their preference into policy (Bicker and Williams, 2001).

The concept of politics has elicited different definitions, opinion and reactions. Easton cited in Orluwene (2007) has defined it as the authoritative allocation of values for a society. The determination of who get what, when and how? Lasswell cited in (Orluwene, 2007). While Ake cited in Nna (2004) defined politics as a system of behaviour by which a society expresses its self-determination by choosing leaders, holding them to evolve, pursue and account collective goals. Ndu (1998:3) on the other hand, see it as resolution of the problems and contradictions which arise from the struggle to satisfy the economic needs of the people, and Wrights cited in Orluwene (2008a) sees it as the act of influencing, manipulating and controlling others in the polity.

Politics therefore, is essentially about the struggle for power in the society. It has to do with decision as to the allocation of scarce resources to the multiplicities of needs of the members of the society. It reflects the competition, conflicts of interest and divergences of opinion which exist in any society. Politics is the exercise of power and authority and the relation of power in any given society which involves the entrustment of the entire treasure and conscience of the society to the core of the elected or appointed representatives of the people, in the best interest of the greatest number of the ordinary people (Orluwene, 2008, 2007).

\section{Development Strategies in Nigeria}

Nigeria on attaining independence in 1960, adopted Liberal/Open Door Policy as the first economic strategy. Government policy at that time was in favour of attracting foreign investors for industrialisation. This act is generally related to many developing countries. This approach sought to forge national policies in a manner designed to exploit the highly sensitive national economy characterising the contemporary third world (Ogbuagu, 1995).

The policy makers argued loudly that for industrial development to be a reality, the country would need massive and unrestricted inflow of foreign capital, technically skilled and managerial manpower and technology from the developed nations. To achieve this intension, the country's policy makers provided many of the fiscal and monetary measures that were introduced in the late 1950s to encourage economic growth. They included (i) Import Duties Relief Act of 1957; (ii) Income Tax Relief Act of 1958; (iii) The Customs "Draw Back" Regulation Act of 1958; (iv) The Company's Income Tax Act of 1961; (v) the Exchange Control Act of 1962, and (vi) The Tax Exemption to Loanable foreign capital (Usoro, 1974).

Regrettably, however, despite all the aforementioned fiscal incentives which were liberal, administrative bottlenecks and infrastructural constraints made it difficult for local and foreign investors to take advantage of the stated incentives and many foreign and local investors were more inclined to the more profitable commercial activities than the manufacturing activities that could meet the country's diversification needs. Above all, criticisms were made that the incentives were excessive and in effect Nigeria did not make much progress from the initial strategy for economic growth and development (Ogbuagu, 1995).

In 1962, the strategy of Import Substitution was adopted, the strategy hoped to replace imported products with goods produced/ manufactured locally in order to reduce the country's dependence on imports especially on consumer goods as to increase the level of national income (NI), lower the level of high unemployment rate and secure a general improvement of the quality of life of its citizenry. In all, this strategy accounts for a significant improvement in the industrial sector. For example, in the early years of its implementation, the country was virtually self-sufficient in the production of certain consumer goods like drinks and other beverages, cotton, soap, textile, tobacco, plastic goods, livestock, feeds, stationery and footwear, among others.

But the momentum did not last long in Nigeria's bid for economic development. Ogbuagu (1995) briefly summarized the reasons for these difficulties as:

(a) Nigeria's dependence on the North for manufactured goods was regrettably worsened by huge increase in the 
import of raw materials, intermediate and capital goods. In fact, at the end, Nigeria found herself in a more precarious dependent condition than was the case when she demanded to make a change.

(b) She inadvertently and indiscriminately engaged herself in an across-the-border development of industries of all kinds without ably selecting the establishment of those industries from which it enjoyed comparative advantage, at least from the point of view of internal sources.

(c) The concentration of over 80 percent of Nigeria's industrial establishment in few urban centres such as Lagos, Enugu, Port Harcourt, Kaduna, Kano, Jos and Ibadan worsened the already adverse urban-rural social and economic inequalities.

(d) Moreso, the excessive protection that was given to local industries, especially from high tariff and other industrial incentives rather than improve things, led to significant industrial inefficiency; and

(e) Above all, most of the industries that were established under import substitution industrialisation strategy were mostly owned, managed and controlled by foreign investors. This gave rise to another strategy often referred to (in Nigeria) as the Indigenisation Policy.

The Nigeria Enterprises Promotion Decree (NEPD) otherwise known as the Indigenisation Policy was part of the economic nationalism. It came into force through a decree in 1972, and later in 1977. The primary focus was to increase the Nigerian businessmen's participation, control and management of the economy. It is also aimed at reversing the domination and control of strategic and commanding heights of the nation's economy by foreigners (FGN, 1972, 1977). In both 1972 and 1977 decrees respectively, business enterprises were categorised under three (3) schedules; (a) small scale and labour intensive, (b) medium and large scale industries and other economic undertakings such as commercial, merchant and development banks, insurance companies, manufacture of goods, petro-chemical, iron and steel industries, among others; (c) enterprises included virtually all large capital intensive industries (FGN, 1972, 1977).

In all, the Indigenisation (NEPD) Policy failed to meet these central/primary objectives meant to turn over the stipulated foreign ownership, management and control of some industries to local Nigerians as a result of the following under-listed factors: (a) Many Nigerian local businessmen prefer a share of the proceeds of the indigenised enterprises to effective participation in, meaningful ownership and control of these ventures; (b) Foreign firms that were affected by the NEPD laws employed various means to circumvent the indigenisation decree. Some of the means include fronting and bribery among others. Much of these were done in collaboration with compradors (Nigerian upper class) businessmen, and (c) The indigenisation (NEPD) policy became an instrument for very few privileged Nigerians namely indigenous businessmen, top military rulers, top public servants and other professionals to amass considerable wealth for themselves through the control and manipulation of state power (Okigbo, 1989).

In the Agricultural Sector, all successive governments had been implementing one agricultural programme or the other. For example, the second National Economic Plan (1970-74) initiated by the Yakubu Gowon administration made agriculture a priority. In 1972, Gowon's administration introduced the National Food Production Programme (NAPP) and the Nigerian Agricultural and Cooperative Bank (NACB) entirely devoted to funding agriculture (Akinwumi, 2000).

Olusegun Obasanjo, during his term as a Military Head of State between 1976 and 1979, initiated a popular agricultural scheme called Operation Feed the Nation (OFN) and abandoned the Gowon programme. The same was the case when Shehu Shagari came to power in 1979 as the first elected president of Nigeria, and shelved Obasanjo's OFN for his Green Revolution programme, which had the twin objectives of curtailing food importation while boosting crop and fibre production. But the "greenness" of the Shagari revolution soon turned "red" when General Muhammadu Buhari grabbed the reins of power in 1983 and introduced the "Back to Land Programme" with variations (Ojo, 1989). His programme gave rise to similar programmes at the State levels with Fidelis Oyakhilome, the then Military Governor of Rivers State, introducing School to Land Programme while his Lagos State counterpart, Golaham Mudasiru, initiated the Graduate Farming Scheme. But like the previous programmes, the Back to Land did not last long (Ojo, 1989).

In 1986, General Ibrahim Babangida, former Military President established the Directorate of Food, Road and Rural Infrastructure (DFRRI). The programme was meant to provide feeder roads, electricity and potable water and toilet facilities for the rural dwellers. It was primarily designed to create the necessary infrastructure to encourage agricultural practice and ease the movement of the products of farming to the urban centers. Regrettably, the project gulped 1.9 billion Naira, yet the rural dwellers had no access to roads to their farms and such programmes went with the winds because of Nigeria's dependence on oil. The consequences, as some analysts have pointed out, include skyrocketing unemployment rate, food crisis, inflation, corruption and poor attitude to work, as governments of the 36 states of the federation now rely on federal allocation from the oil revenue to run their states (Ezeoke, 2011). This is unlike in the 1960s when Nigeria operated a mixed economy that made her the world's largest exporter of groundnuts, palm produce; and the third largest exporter of cocoa. Specifically, at that time, Nigeria accounted for $60 \%$ of the global supply of palm 
oil, $30 \%$ of groundnuts and $15 \%$ of cocoa.

The diversity of these natural resources also gave each region of the country a mark of identity. For example, palm produce was grown in eastern region, cocoa in the western region, and groundnut in the northern region. To keep their identities, government of each region frantically made efforts to ensure that it was not outdone by others (Ezeoke, 2011).

Still in search for a viable strategy for the economy as a result of failure of the previous strategies, Nigeria adopted the Structural Adjustment Programme (SAP) strategy, which started with a conference in November, 1984, organised by the Nigerian Institute of Social and Economic Research (NISER) and the Federal Ministry of National Planning. The objective of that meeting was to discuss strategies for the (a) Diversification of the nation's economy away from the monocultural one to which it had been pushed by the fortunes of the oil sectors; (b) Revitalisation of the agricultural sector with a view to achieving self-sufficiency in food production. This was to be achieved through a rural integrated development programme; (c) Domestic production of raw materials for local industries in order to reduce the import content of local, manufactured goods, and (d) Promotion of employment opportunities in order to arrest deteriorating mass employment (Okojie, 2003:362-363).

However, by this time, Nigeria's external debt (outstanding and disbursed) amounted to about 2.2 billion Dollars. The country was caught up in an export credit squeeze. She, therefore, had to come to terms with some of the conditionalities given by her external creditors for rescheduling her debts. Towards the middle of 1986, Nigeria embarked on the SAP, which aimed at restructuring and diversifying the productive base of the economy in order to reduce dependence on the oil sector and on imports (Obadan, 1993).

Other objectives of SAP included the following: (a) achievement of fiscal and balance of payment viability over the medium term; (b) laying the basis for a sustainable non-inflationary or minimal inflationary growth, and (c) lessening the dominance of unproductive investments in the public sectors, improving the sector's efficiency and increasing the growth potential of the private sector.

The core policies of SAP were to: (a) correct the serious over-valuation of the Naira through the establishment of a viable Second-tier Foreign Exchange Market (SFEM) along with adjustments of the official rate to achieve eventual convergence of the two exchange rates within a short period; (b) overcome public sector inefficiency through improved public expenditure control programme and the speedy rationalisation of the parastatals, and (c) relieve the debt burden and attract new inflow of foreign capital, while keeping a lid on fresh foreign loans (Okojie, 2003:363).

Various complementary policies and programmes were also put in place such as the establishment of DFRRI and National Directorate of Employment (NDE), reform of the Civil Service and the introduction of the Urban Mass Transit Programme (Obadan and Ogiogio, 1992).

However, the objectives of SAP were not achieved within the two-year period; SAP was supposed to be in place (1986-1988). SAP policies continued to be implemented along after 1988. In general, SAP marked a shift from the project-based to policy-based economic management. In the manufacturing sector, policy shifted from public sector direct involvement in the economy to that of strengthening the macro-economic sector to assume a leading role in manufacturing. Many of the objectives of SAP are yet to be realised, privatisation, commercialisation and deregulations among others that are components of SAP are still ongoing and on course (Orluwene, 2013).

\section{Concluding Remarks}

This study conceptualised the concept of development, policy and politics. It discussed the meaning of these concepts. The study also traced the history, principles and objectives of the various development strategies in Nigeria since independence. It shows that even though the strategies begins on a search for viable options for national development, it realisation remained a wide mirage due to the wide issues covered under the politics of non-continuity and lack of accountability of previous policies by various administrations in Nigeria. Each administration in Nigeria often initiates its own policies and programmes despite the laudable objectives of previous administrations policies.

It therefore recommends that for Nigeria to realise its potential and reap the benefit of the development strategies/policies, there is urgent need to tailor the formulation and implementation of policies in a manner that will address the socio-economic challenges facing Nigeria. Essentially, government policies and decision in Nigeria should be people-centred and people-oriented and not that of government in power or elites.

Corrupt elements and practices should be urgently and quickly identified and tackled without any fear or favour, so that the huge leakages associated with the politics of non-continuity and lack of accountability could be curbed. These would make the conversion and transformation of the nation's abundant human and material resources into prosperity for the greatest happiness for the greatest number. 


\section{References}

Ake, C. (1981). A political economy of Africa. London: Longman Publishers.

Akinwumi, J. (2000). "Investment in agriculture". A paper presented to Job for Africa: Poverty reduction employment strategies for SubSaharann African (JEA-PRESSA) programme, Sheraton Hotels and Towers Abuja, 24-25 July, P. 10.

Akpan, N.U. (1982). Public administration in Nigeria. Lagos: Longman Nigeria.

Ayida, A.. (1987). Reflection on Nigerian development. Lagos: Malthouse Press Ltd.

Bicker, R.N. \& J.A. Williams (2001). Public policy analysis: a political economy approach. Boston: Houghton Miffin.

Eme, O.I. \& C.C. Onwuka (2011). "Political economy of deregulation policy in Nigeria: the challenges ahead". Journal of Business and Organisational Development 2, P. 5.

Ezeoke, J. (2011). "Obstacle to food security". Tell Magazine, August 8, Pp. 48-49.

FGN (1972) Nigerian Enterprises Promotion Decree No. 4. Lagos: Federal Government Printers.

FGN (1977). Nigerian Enterprises Promotion Decree: Supplement of official gazette 64(2) part A. Lagos: Federal Government Printers.

Hills, M. (ed) (1973). The Policy Process: A reader. London: Harvester Wheatsheaf.

Ndu, Eme (1998). Ancient and medieval political theory: an introduction. Owerri: Springfield Publishers.

Nna, N.J. (2004). Contemporary political analysis (2nd edition). Owerri: Springfield Publishers.

Nnadozie, U.O. (2004). The state, civil service and underdevelopment in Nigeria: An Analysis of Public-making process in a neo-colonial society. Enugu: Johnkens \& Willy Publications Ltd.

Nwaorgu, O.C. (2006). Monopoly capitalism and the development tragedy: a study in imperialism, globalisation and underdevelopment. Port Harcourt: Amajov and Co. Nig.

Obadan, M.I. \& Ogiogio, G.E. (1992). "Thirty years of national planning in Nigeria: Some lessons and experiences". In JJ.O. Umoh (ed.) Economic transformation through national planning in Nigeria. Abuja: National Planning Commission.

Obadan, M.I. (1995). "Privatisation and commercialization of public enterprises in Nigeria". NECEMA Policy Analysis Series 1 (1) Pp. 122.

Ogbuagu, C.S.A. (1995). Nigeria development policies and programmes. Calabar: The University Press.

Ojo, M.O. (1989). "The design of an operation framework of perspective planning for Nigeria Agriculture". The Nigerian Journal of Economic and Social Studies 13(1-3) pp. 190-203.

Okigbo, P. (1989). National development planning in Nigeria: 1990-92. Enugu: Fourth Dimensions Publishers.

Okojie, C.E.E. (2003) "Development planning in Nigeria since Independence" in M.A. lyoha \& C.O. Itsede (eds.) Nigeria economy: structure, growth and development. Benin-city: Mindex Publishers.

Onyishi, T. (2010). "The policy process: an overview of concept and procedures" In R.C. Onah \& C.N. Oguonu (eds) Readings in public administration. Nsukka: University of Nigeria Press.

Orluwene, O.B. (2007). The politics of grassroots governance in Nigeria. Port Harcourt: Ulamba Publishers.

Orluwene, O.B. (2008)a . "Politics of Revenue allocation in Nigeria since independence: An Overview" In Multidisciplinary Journal of Empirical Research 5(1) PP. 101-114.

Orluwene, O.B. (2008)b. "Corruption and Development in Nigeria" in the Nigerian Academic Forum: A Multidisciplinary Journal 15(1) PP. 121-131.

Orluwene, O.B. (2013). The bureau of public enterprises and privatization of Nigerian public enterprises, 1999-2007. A Ph.D thesis submitted to University of Nigeria Nsukka (Unpublished).

Osman, F.A. (n.d) Public policy making: theories and their implications in developing countries. Asian Affairs.

Usoro, E.J. (1974). "Government policies, politics and industrial development strategies in Nigeria: 1947-1974". The Nigerian Journal of Economic and Social Studies, 6 (2) July, PP. 20-31. 